\title{
UNDERSTANDING THE ESSENCE OF MOOD DISORDERS THROUGH THE EYES OF POETRY
}

\author{
Gulbahar S. Sidhu MD ${ }^{1}$ \& Deepali Gul MD ${ }^{2}$ \\ 1 Consultant Psychiatrist, Doaba Hospital, Jalandhar (Punjab), India. \\ 2 Associate Professor, Department of Psychiatry, Punjab Institute of Medical Sciences, Jalandhar (Punjab), India.
}

Cite as: Sidhu, G.S. \& Gul, D. (2021) Understanding the essence of mood disorders through the eyes of poetry. Sushruta J Health Policy vol 14; Issue 1: 1-5 ePub 22.01.2021 DOI https://doi.org/10.38192/14.1.9

Article Information

Submitted 21.01.2021

Pre-print 22.01.2021

"If we take a look at creative ideas outside of science like poetry, art, music, these ideas can link us to knowledge of the brain which in turn will better our future."

Barack Obama

Psychiatric disorders have a history as old as mankind. The ancient literature is replete with vivid descriptions of various afflictions of the mind. Throughout history, the human intellect has assiduously tried to classify illnesses on the basis of common features between them. In fact, this tendency to classify extends far beyond the realms of illnesses to include virtually all phenomena that occur around us.

Though, the continued effort to classify and subclassify mental illnesses has helped in increasing our understanding and helped in carrying out research, it has its own inherent drawbacks. One of the major drawbacks relates to losing the very essence of the mental illnesses in the jargon of coding and classification. For instance, understanding depression from a medical standpoint does not help clinicians understand the way in which an individual constructs and understands their depression, both personally and culturally. ${ }^{1}$
Poetry and medicine, at first sight, seem an unlikely pairing. ${ }^{2}$ A closer look, though, reveals a different perspective. Poetry is characterized by compression, an economy of words, image and metaphor and, hence, a poem has the capacity of capturing the depth of human experience. ${ }^{3,4}$ It is said to transcend formal logic and be more faithful to the logic of emotion. ${ }^{4}$

\section{Could poetry help in rediscovering this lost essence?}

This is the basic question that this research paper attempts to answer. We will be focusing on poetry related to Mood disorders in our present endeavor.

We believe that poetry can help us gain perspective which technical jargon is never able to convey. An analysis of poetry opens a new door to explore alternative methods of understanding mood disorders. An examination of the styles, diction, metaphor, simile used in the poems can help discover how mental illnesses can be understood outside the world of neurons and neurotransmitters. Such an analysis may help find a way for society to better understand individuals suffering from mental illnesses. ${ }^{5}$ 


\section{Portrayal of Depression in Poetry}

The Diagnostic \& Statistical Manual - $5^{6}$ outlines the following criterion to make a diagnosis of depression. The individual must be experiencing five or more of the following symptoms during the same 2 -week period and at least one of the symptoms should be either (1) depressed mood or (2) Anhedonia or loss of interest or pleasure.

- Depressed mood most of the day, nearly every day.

- Markedly diminished interest or pleasure in all, or almost all, activities most of the day, nearly every day.

- Significant weight loss when not dieting or weight gain, or decrease or increase in appetite nearly every day.

- A slowing down of thought and a reduction of physical movement (observable by others, not merely subjective feelings of restlessness or being slowed down).

- Fatigue or loss of energy nearly every day.

- Feelings of worthlessness or excessive or inappropriate guilt nearly every day.

- Diminished ability to think or concentrate, or indecisiveness, nearly every day.

- Recurrent thoughts of death, recurrent suicidal ideation without a specific plan, or a suicide attempt or a specific plan for committing suicide.

There are numerous examples in English Poetry which elucidate the core symptoms of depression. Samuel Taylor Coleridge's classic lyrical ballad, "The Rime of the Ancient Marine" 7 describes the core symptoms of depression i.e. depressed mood and anhedonia wonderfully thus:

All in a hot and copper sky,

The bloody Sun, at noon,

Right up above the mast did stand,

No bigger than the moon.

Day after day, day after day,

We stuck nor breath nor motion

As idle as a painted ship

Upon a painted ocean.

Water, water everywhere

Nor any drop to drink.

Alone, alone, all, all alone,

Alone on a wide, wide sea!

And never a saint took pity on

My soul in agony.
Coleridge, in this poem, uses the metaphor of a ship to represent the mind. He describes the mental state of depression by using the phrases like "idle....painted ship" that is "stuck" with no "breath or motion." The frozen state of mind of a depressed patient is described by Coleridge as "a painted ship upon a painted ocean." Depression is associated with a mental state where nothing can alleviate the all pervasive sadness of mood. This is beautifully captured by Coleridge as he writes "Water, water everywhere........Nor any drop to drink." The poet continues to describe the feelings of loneliness by deftly repeating the word "alone" three times in the last stanza. "Never a saint to pity on me" points to the hopelessness often endured during bouts of depression.

Another poem which vividly captures the essence of depression is "Melancholia" by Charles Bukowski (1920-1994) ${ }^{8}$.

...me, I writhe in dirty sheets

While staring at blue walls

And nothing.

I have gotten so used to melancholia

That

I greet it like an old

Friend.

.... listen to drums on the radio now

And grin

There is something wrong with me

Besides

Melancholia.

Bukowski describes his melancholic state by "staring at blue walls" and feeling "nothing." William Wordsworth's "The World is Too Much With Us"9 describes anhedonia in his own unique way thus:

This sea that bares her bosom to the moon

The winds that will be howling at all hours

And are up-gathered now like sleeping flowers

For this, for everything, we are out of tune.

Emily Dickinson (1830-1886) is another poet noted for poignant portrayal of depression. In her poem "It was not Death, for I stood up", she describes the absence of feeling by writing that it felt as if her "life was shaven and fitted to a frame, and could not breathe without a key."10 
It was not Death, for I stood up, And all the Dead, lie downIt was not Night, for all the Bells Put out their Tongues, for Noon.

It was not Frost, for on my Flesh I felt Siroccos-crawlNor Fire-for just my Marble feet Could keep a Chancel, cool-

And yet, it tasted, like them all, The Figures I have seen Set orderly, for Burial, Reminded me, of mine-

As if my life were shaven, And fitted to a frame, And could not breathe without a key, And 'twas like Midnight, some -

When everything that ticked - has stoppedAnd Space stares-all aroundOr Grisly frosts-first Autumn morns, Repeal the Beating Ground-

But, most, like Chaos-Stopless-coolWithout a Chance, or SparOr even a Report of LandTo justify-Despair.

The poem's final stanza imagines the state of depression as a sort of shipwreck. The poet is all at sea, marooned from her fellow man, just as depression can isolate us from the world around us by the use of words like "Not even a Report of Land."

Another $19^{\text {th }}$ century poet, Gerard Manley Hopkins penned a collection of verses known as the "Terrible Sonnets" or "Sonnets of Desolation" which capture the essence of depression quite well. ${ }^{11}$ Loneliness and isolation is depicted in the sonnet "To seem the stranger lies my lot/my life among strangers." Low mood, especially on rising is described as "I wake and fell the fell of dark, not day." Another sonnet;

"Selfyeast of spirit a dull dough sours. I see/ The lost are like this, and their scourge to be/ As I am mine, their sweating selves; but worse"

portrays the feeling of self-loathing vividly. Internal restlessness is depicted thus "We hear our hearts grate on themselves." Henry Howard, Earl of Surrey (1516-1547) was the poet credited with the invention of the Shakespearean sonnet. In one of the first sonnets written in English titled "The Soote Season" describes the various hues of spring wherein each thing renews ranging from the scale of the fishes, the "swift swallow", to the "busy bee" yet the poet's sorrow "springs among all pleasant things." 12

Somer is come, for euery spray nowe springes,

The hart hath hong his olde hed on the pale:

The buck in brake his winter cote he flinges:

The fishes flote with newe repaired scale:

The adder all her sloughe awaye she slinges:

The swift swalow pursueth the flyes smale:

The busy bee her honye now she minges:

Winter is worne that was the flowers bale:

And thus I see among these pleasant thinges

Eche care decayes, and yet my sorow springes.

John Keats' "Ode on Melancholy" (written in 1819) goes a step further to offer some advice on how to deal with a dose of the doldrums.

No, no, go not to Lethe, neither twist Wolf's-bane, tight-rooted, for its poisonous wine; Nor suffer thy pale forehead to be kiss'd By nightshade, ruby grape of Proserpine

She dwells with Beauty - Beauty that must die;

And Joy, whose hand is ever at his lips

Bidding adieu; and aching Pleasure nigh,

Turning to poison while the bee-mouth sips:

Ay, in the very temple of Delight

Veil'd Melancholy has her sovran shrine,

Keats advises "not to go to Lithe (ancient Greek river associated with forgetfulness) by taking to drugs or by "kissing the nightshade", suggesting deadly nightshade, a metaphor for committing suicide. Keats goes on to suggest that looking upon pleasurable things and reflecting that they will soon die, surprisingly cheer us up ("She dwells with Beauty - Beauty that must die; And joy, whose hand is ever at his lips bidding adieu; and aching pleasure nigh, turning to poison while the bee-mouth sips"). ${ }^{13}$ The list of poems that capture the essence of depression is a long one. What we have tried to do is to feature a few of them.

\section{Portrayal of the Manic State and Bipolar Illness}

The maniacal state is a unique one characterized by elevated mood. There are many examples in the annals of English poetry which describe this mental state almost perfectly. Emily Dickinson's poem "The first day's Night had come" is one such poem ${ }^{14}$.

The first Day's Night had come-

And grateful that a thing

So terrible-had been endured- 


\section{I told my Soul to sing-}

She said her Strings were snapt-

Her Bow-to Atoms blown-

And so to mend her-gave me work

Until another Morn-

And then-a Day as huge

As Yesterdays in pairs,

Unrolled its horror in my face-

Until it blocked my eyes-

My Brain-begun to laugh-

I mumbled-like a fool-

And tho' 'tis Years ago-that Day-

My Brain keeps giggling-still.

And Something's odd-within-

That person that I was-

And this One-do not feel the same-

Could it be Madness-this?

She uses phrases like "I told my Soul to sing", "Her strings were snapt", "Her Bow to Atoms blown."

The lack of insight into one's illness is described wonderfully as "blocking the eyes."

The phrases like "My brain begun to laugh" and "My brain keeps giggling" gives a vivid description of a maniac state. Samuel Taylor Coleridge in his lyrical ballad "The Rime of the Ancient Marine" weaves the maniacal state by using the phrases "Souls .....from their bodies fly", "They fled to bliss, like the whizz of my crossbow." Coleridge continues "Fly, brother, fly! More high, more high!" to describe the sustained elevated mood.

The swings of mood from extreme depression to severe mania have been vividly captured by different poets. Samuel Coleridge's "The Rime of the Ancient Marine" describes the bipolar illness beautifully as the first couple of stanzas portraying the dark days of depression gives way to the heady days of mania.

\section{Potential Utility of Poetry in Mood Disorders}

- Use as teaching aids for better understanding of the illness.

- The patients could explain their symptoms in a better way by way of poetry as it is one of the few media of public communication that can be (more or less) trusted to represent honestly and authentically the truth. ${ }^{1}$
- More patients could be identified as suffering from mood disorders not fulfilling the required diagnostic criteria.

- Poetry tends to stick in the memory because of its intrinsic rhythms and so helps the patients as well as the clinicians to retain the lessons learnt from them. ${ }^{15}$

- The use of poetry to describe the symptoms of various psychiatric disorders has the potential to take their description back to the narrative form, away from the tabulated forms, so characteristic of the newer textbooks and diagnostic manuals.

To conclude, poetry, far from being "an unusual pairing" with medicine, helps us to rediscover the complicated emotions associated with psychiatric disorders which can so easily be lost when we merely focus on the technical aspects alone.

\section{Declaration of conflict of Interest}

none

\section{REFERENCES:}

1. John F. Sherry, Jr., John W. Schouten, A Role for Poetry in Consumer Research, Journal of Consumer Research, Volume 29, Issue 2, September 2002, Pages 218234, https://doi.org/10.1086/341572

2. Singer DR, Hulse M. Poetry, medicine, and the international Hippocrates Prize. Lancet 2010;375:976-977. https://doi.org/10.1016/S01406736(10)60427-8

3. Furman, Rich and Bender, Kimberly (2003) "The Social Problem of Depression: A Multitheoretical Analysis," The Journal of Sociology \& Social Welfare: Vol. 30 : Iss. 3, Article 8 Available at:

https://scholarworks.wmich.edu/issw/vol30/is $\underline{s 3 / 8}$

4. Keates, J. Ode on Melancholy. Available at; https://www.poetryfoundation.org/poems/444 78/ode-on-melancholy

5. Loberg E. The groundbreaking link between mental illness and literature, Part 1

6. American Psychiatric Association (2013). Diagnostic and Statistical Manual of Mental Disorders (5th ed.). Arlington, VA: American Psychiatric Publishing. https://doi.org/10.1176/appi.books. 978089042 $\underline{5596}$

7. The Rime of the Ancient Mariner Samuel Taylor Coleridge (1798) Available from 
https://resources.saylor.org/wwwresources/ar chived/site/wp-

content/uploads/2014/05/ENGL404-Coleridge-

The-Rime-of-the-Ancient-Mariner.pdf

8. Bukowski, C. Melancholia. Available from

https://readalittlepoetry.wordpress.com/2006/

04/22/melancholia-by-charles-bukowski/

9. Wordsworth, W. The World is too much with us. Available from

https://www.poetryfoundation.org/poems/455

64/the-world-is-too-much-with-us

10. Dickinson, E. It was not death for I stood up.

Available from

https://www.poetryfoundation.org/articles/68

930/emily-dickinson-it-was-not-death-for-istood-up

11. Manley Hopkins G. Six sonnets of Desolation.

Available from:

http://www3.sympatico.ca/kronenfeld/pages/

Hopkins.html

12. Willis P. (2002). Poetry and Poetics in

Phenomenological Research. Indo-Pacific

Journal of Phenomenology. 3(1): 1-19. Available

from https://philpapers.org/rec/WILPAP-15

13. Howard, H. The Soote Season. Available from; https://www.poetry.com/poem/17417

14. Dickinson, E. The first day's night had come.

Available from

http://www.famouspoetsandpoems.com/poets/ emily dickinson/poems/9647

15. Stammers T., Healing Allusions: The Use of

Poetry in Medical Education. Journal of

Contemporary Medical Education 2015;

3(3):127-133. Available from

https://www.researchgate.net/publication/283 624643 Healing Allusions The Use of Poetry I n Medical Education 